\title{
Contando histórias: "Cada bicho com seu rabicho" e "Dançando até o rio"
}

\author{
Hatsuya Kimura
}

Desde tempos imemoriais, o homem narra sua história por meio de sons, imagens ou palavras. Contar uma história é transmitir fatos, reais ou não, quase sempre improvisando, aumentando, diminuindo, melhorando... mas, em todas as culturas, histórias ou narrativas são compartilhadas como forma de entretenimento, informação, educação, preservação cultural, e com a finalidade de inculcar valores morais. Supõe-se que as formas mais antigas de narrativa tenham sido essencialmente orais, combinadas com gestos e expressões. Além de serem parte de rituais religiosos, desenhos rudimentares em rochas podem ser formas das primeiras narrativas para muitas culturas antigas. Os aborígines australianos pintavam símbolos das histórias nas paredes das cavernas como meio de ajudar o contador de histórias a não esquecer algum detalhe. Nas comunidades aborígines, a comunicação oral é muito valiosa e amplamente usada para passar conceitos e crenças através dos tempos. As narrativas são parte integrante da vida dos aborígines australianos e, desde muito cedo, elas têm um papel crucial na educação das crianças. As histórias ajudam a entender o passado, o presente e o futuro: ajudam a explicar como e quando a terra veio a ser habitada, onde encontrar alimentos, como se portar e por quê. Enfim, as "Histórias da Época do Sonho" constituem a primeira parte da educação de uma criança, e o povo aborígine continua a divulgá-las, de uma geração à outra, com o intuito de preservar o respeito próprio, a autoestima e a dignidade e, principalmente, de construir e manter a identidade cultural. Atualmente, essas tradições orais são expressas de várias outras formas: nas artes visuais, no teatro, na música, na dança, na literatura, no rádio ou no cinema, na televisão ou em CDs, na Internet... 
As autoras aqui traduzidas são storytellers. Mona Green é contadora de histórias do povo Jaru, da Austrália Ocidental, interessada na preservação das lendas e mitos do seu povo e na alfabetização de crianças. É também de sua autoria The Echidna and the Shade Tree (1984), cujas ilustrações foram adaptadas a partir dos desenhos que as crianças ouvintes fizeram no decorrer da narrativa. Grace Hallworth, também contadora de histórias, é autora de vários livros infantis, tais como Down by the River, Going to School, Sing Me a Song, Rhythm and Rhyme, publicados ao longo dos últimos vinte anos. Sempre recorrendo às suas raízes caribenhas, pois cresceu na Trinidad dos anos 1930, ela se serve do folclore caribenho, rico em elementos de origem africana, com suas fábulas, rimas, canções e danças, para incentivar as crianças, não apenas a ler, mas também a cantar $e$ dançar. Apenas contando, isto é, valendo-se somente da voz, gestos e expressões, ou escrevendo para contar, ou traduzindo para contar, é essencial lembrar que o público que se pretende atingir é muito especial. $\mathrm{Na}$ verdade, livros infantis se destinam ao público infantil e adulto ao mesmo tempo, pois são normalmente os adultos, pais ou professores, os responsáveis pela iniciação da criança na literatura.

How the Animals Got Their Tails e Dancing to the River têm estruturas sintáticas dinâmicas, com orações coordenadas e subordinadas curtas, explícitas, de fácil compreensão, com certa redundância, conferindo clareza e propiciando grande legibilidade. $O$ papel didático que esses contos certamente têm dentro da Literatura Infantil, somado às qualidades citadas, aumenta a responsabilidade do(a) tradutor(a) que, ao manipular esse tipo de texto, deve tentar preservar tais características. Eu não sabia que título colocar no primeiro conto até algum tempo atrás, quando acabei me decidindo por Cada Bicho com Seu Rabicho. "Rabicho", para dar um certo 'ar' de gente aos bichos, não só por questão de rima. Para me referir a tail, usei "cauda, rabo, rabinho, rabicho e rabicó"; talvez atraia mais a atenção da criança, e seria uma forma de ser solidária com a maneira de ser dessa criança leitora. Mantive também a profusão de pronomes, pessoais e possessivos, e a repetição de substantivos e verbos, pois essa redundância seria uma forma de fixar vocabulário e estruturas gramaticais, no início da alfabetização. Na fábula caribenha Dancing to the River, os verbos turn around, leap, twirl, spin e prance foram traduzidos por "dar uma volta, saltitar, girar, rodopiar e saracotear"; mesmo não sendo as melhores soluções, esses verbos dão uma boa ideia de movimento, uma vez que o elemento musical e a expressão corporal são importantes na narrativa dos contos caribenhos. Além da música e da expressão corporal, 
outro elemento importante e enriquecedor na narrativa de uma história é a interpretação pessoal do contador de histórias. Meu avô japonês costumava contar histórias quando meus irmãos e eu éramos crianças. Ele imitava coisas e animais e os sons que eles produziam. Foi pensando nisso que tentei imitar o som da água quando a Dona Tartaruga apareceu no rio, acrescentando 'chape, chape' antes do verbo 'chapinhar', e para o bater de asas, usei 'fru-fru, fru-fru'. Diferentemente do idioma japonês, em que as expressões onomatopaicas são parte integral da linguagem escrita e falada de crianças e adultos, constituindo um universo à parte dentro do idioma, na nossa língua as onomatopeias não estão normalmente dicionarizadas; são vistas como linguagem infantil e não estão integradas na maneira de falar dos adultos. Entretanto, 'chape' ou 'chape-chape' e 'fru-fru' são expressões que constam dos nossos dicionários: as primeiras referem-se ao som de algo batendo na água ou de passos em terreno lamacento, e a última refere-se ao rumor de folhas ou de asas em voo.

Espero que esses dois contos sirvam para plantar uma sementinha de curiosidade no fértil terreno da imaginação, que só as crianças são capazes de ter, ampliando seus horizontes pelo resto de suas vidas.

\section{How the Animals got Their Tails}

My father told us this story. He told us lots of stories, really. They were going on before white people reached Australia. They were passed on from our old people to young people. As a matter of fact, they are still going on. We still share them around - just like my father did. This is a true story. It's a Dreamtime story.

In the Dreamtime, before there were any people around, the animals did things just like human beings do today. They were the bosses of this country.

They did things like have big corroborees, where everyone got together for a meeting to sing and dance. These ceremonies were very important and the animals travelled from all over the place to be there. We Aboriginal people still do this today.

The animals mostly had their corroborees at night. Sometimes they went on for five or six nights. Every night the animals met at their special place. They sang and danced. Everyone was happy. It was always a big event.

But before they reached the main corroboree camp, there was something they always did. 
They took off their tails! Then they hung them up in the branches of a tree, some high, some low, all over the tree. They didn't want to leave them just lying on the ground.

That tree was full of tails. The animals just left them hanging there while they went off to join in the singing and dancing.

Well, one night all the animals came to their special place. They did what they had always done. They took off their tails and hung them on the tree - some high, some low. They hung them all over the tree and then went off to join in the singing and dancing.

Nobody noticed that a bush fire had started! They were too busy dancing and singing. At first it wasn't burning that big. The animals were dancing, dancing, singing, singing.

That fire got bigger and started coming towards them, burning bright. The animals just kept on dancing.

Then they felt the heat. They looked up and saw this big flame above them.

And then they remembered their tails.

Well, they all rushed to the tree. They were running around. It was hot. Smoke and flames were everywhere.

Soon there was this big mob of animals crowded around the tree-all trying to find their tails. They grabbed the first tail that they could see.

They were in the much of a hurry, they just grabbed any tail. Some of them grabbed the wrong one, maybe a tail belonging to someone else. But they didn't notice. They just wanted to escape from the fire. They pulled the tails off the tree, stuck them on and then they ran off, away from the flames.

Some were too late and their poor tails were burnt, all burnt up! And those animals lost their tails for ever.

Today, you can see that animals have all sorts of strange-looking tails. Some have no tails at all. That's because their tails got burnt up.

Pigs have short, curly tails - not really big. And what about wallabies? Some wallabies have black tails - those tails might have been half-burnt, you know, scorched.

Rabbits and camels have very short tails. If you look at goats, you'll see they have funny little tails. Possums have bushy tails and some even have bald tails. 
Horses have long, thick tails. Kangaroos, too, they have big, heavy tails. Maybe they got the wrong ones and just stuck them on.

Watch some animals, like dogs. When they meet each other, they sniff each other's tails. Do you know why? They are looking, looking, looking - trying to find their own tails.

Some animals don't do that because they are satisfied that they got the right ones.

So remember, when you see animals sniffing each other's tails, the reason is that they are still worrying about their own tails and hope that one day they will find them.

My father told me this story when we were kids. He told all my brothers and sisters, too. And now I am telling all my grandchildren and great-grandchildren. And you, too.

\section{Cada bicho com seu rabicho (ou Como os animais conseguiram suas caudas)}

Meu pai nos contou esta história. Na verdade, ele nos contou muitas histórias. Histórias que se passaram antes da chegada do homem branco à Austrália. Histórias contadas pelos mais velhos aos mais jovens. De fato, elas continuam sendo contadas. Ainda compartilhamos as histórias, exatamente como meu pai fazia. Esta é uma história verdadeira. É uma história da Época do Sonho.

$\mathrm{Na}$ Época do Sonho, antes de aparecerem as pessoas, os animais faziam coisas exatamente do jeito que os humanos fazem hoje. Os animais eram os senhores desta terra.

Eles faziam coisas como realizar grandes corroborees, em que todos se reuniam para cantar e dançar. Eram cerimônias muito importantes e os animais vinham de todos os lugares para se encontrarem lá. Nós, aborígines, ainda fazemos o mesmo hoje.

Os animais, quase sempre, realizavam seus corroborees à noite. Às vezes, esses festivais duravam cinco ou seis noites. E a cada noite, os animais se encontravam num lugar especial. Cantavam e dançavam. Todo mundo era feliz. Era sempre um grande acontecimento.

Antes, porém, de chegarem ao local do corroboree, havia uma coisa que eles sempre faziam. 
Tiravam as suas caudas! Tiravam as caudas e as penduravam nos galhos de uma árvore, algumas acima, outras abaixo, pela árvore toda. Eles não queriam deixá-las largadas no chão.

A árvore ficava cheia de caudas. Os animais as deixavam penduradas lá, enquanto iam ao encontro para cantar e dançar.

Ora, uma noite, todos os animais vieram ao lugar marcado. Fizeram o que sempre costumavam fazer. Tiraram as suas caudas e as penduraram na árvore - algumas acima, outras abaixo. Eles as penduraram pela árvore toda e, a seguir, foram ao encontro para cantar e dançar.

Ninguém percebeu que um incêndio começara na mata! Eles estavam ocupados demais, dançando e cantando. No começo, o fogo não era tão grande. Os animais dançavam e dançavam, cantavam e cantavam.

O fogo cresceu e começou a avançar na direção deles, queimando com força. Os animais continuavam a dançar.

Então, eles sentiram o calor. Olharam e viram a enorme labareda acima deles. E lembraram-se das caudas.

Todos se precipitaram para a árvore, correndo muito. Estava quente. Havia fumaça e chamas por toda parte.

Logo havia uma multidão de animais alvoroçados ao redor da árvore - todos tentando encontrar suas caudas. Agarravam a primeira que enxergavam.

Estavam tão apressados que agarravam qualquer cauda. Alguns agarraram a cauda errada, talvez uma que fosse de algum outro. Mas eles não percebiam. Só queriam escapar do incêndio. Arrancavam a cauda da árvore, colocavam neles e saíam correndo, fugindo das chamas.

Alguns chegaram tarde demais e suas pobres caudas se queimaram, todinhas! E esses animais perderam as suas caudas para sempre.

Hoje vemos animais com todo tipo de caudas esquisitas. Alguns até ficaram rabicós. É porque as suas caudas se queimaram no incêndio.

Os porcos têm rabinhos curtos e enrolados. E os pequenos cangurus? Alguns têm rabos pretos - talvez eles tenham sido, sabem, meio queimados, sapecados.

Os coelhos e os camelos têm rabinhos muito curtos. Se você olhar para os bodes, verá que eles têm rabinhos engraçados. Os gambás têm rabos peludos, mas alguns têm rabos carecas. 
Os cavalos possuem caudas espessas. Os cangurus também têm caudas grandes e pesadas. Talvez tenham pegado as caudas erradas e simplesmente as puseram neles.

Observe alguns animais como os cachorros. Quando se encontram, cheiram as caudas um do outro. Sabem por quê? Eles estão olhando, procurando, olhando - tentando encontrar as suas próprias caudas.

Alguns animais não fazem isso porque estão satisfeitos por terem encontrado as caudas certas.

Então, lembrem-se, quando virem animais cheirando as caudas uns dos outros, é porque eles ainda estão preocupados com as suas caudas e têm esperança de encontrá-las algum dia.

Meu pai me contou esta história quando éramos crianças. Ele contou para todos os meus irmãos também. E agora estou contando para todos os meus netos e bisnetos. E pra você também.

\section{Dancing to the river}

Once upon a time, and a very long time ago, the animals of the forest set out to look for food.

The birds flew high above the trees, searching.

The squirrels dug up all their hiding-places, searching.

The monkeys swung from tree to tree, searching. They found nothing.

Not very far away, there was a field with plenty of corn. When the animals heard about the field, they rushed off to find it. The birds flew off, too.

Turtle was paddling in the river. She saw the birds flying off. They flapped their wings, klak! klak! klak!

It was quiet in the forest, and Turtle was lonely. So she decided to follow the birds and the animals.

Turtle went along until she came to a large field. There she saw her friends stuffing themselves with ripe corn.

The birds called to Turtle, 'Go away, Turtle! Go away, or Watchman will catch you."

Turtle said, "Don't worry about me. I'll keep a sharp look-out for Watchman." 
But, once Turtle was in the field, the corn was too high for her to keep a look-out. his hand.

Suddently, there was Watchman. He was standing with a stick in

The birds flapped their wings and flew away, klak! klak! klak! They left Turtle alone.

"Aha!" said Watchman. "Here's one thief who won't get away."

He grabed Turtle and put her in his bag.

As Watchman walked across the field, he sang a song. It was a calypso, with such a lively tune that Turtle's feet just itched to dance.

Now, Turtle loved to dance more than anything. So when she heard Watchman singing, she called out, 'Hey, Watchman, that's a real sweet calypso, man!"

"You like my song? I make up the words, you know," said Watchman.

"True!" said Turtle, "I can make up songs, too."

"Well, why don't you make up a song for me now?" asked Watchman.

Then Turtle said, "You see, when I sing I like to dance, and I need plenty of space."

So Watchman took Turtle out of the bag and placed her on the ground.

Turtle began to sing a song. As she sang, she made movements with her feet.

She danced to the right and she turned around.

She danced to the left and she turned around.

She leaped and she danced.

She twirled and she pranced.

She was dancing to the river.

It was an easy tune to sing. It was a lively tune to dance to. Soon Watchman was dancing, too. He moved in time to the rhythm. He shook his shoulders and he clicked his fingers.

And he danced to the right and he turned around.

He danced to the left and he turned around.

He leaped and he danced.

He twirled and he pranced.

And he danced his way to the river. 
Turtle danced faster and faster, and she made bigger and bigger steps.

Watchman was trying to keep in time with Turtle.

Turtle spun on her toes, she leaped and she twirled.

Watchman followed every spin and leap and twirl.

He didn't notice where Turtle was heading, until he heard a loud SPLASH!

Turtle had dived into the river and had swum away.

Turtle's Dance

Let's sing and dance to the tay-lay-lay,

Let's turn and prance to the tay-lay-lay.

Hear the music playing

And the steel pan drumming,

As we sing and we dance to the tay-lay-lay.

When the music is good, you've got to dance! Turtle's in danger, but still she dances...

\section{Dançando até o rio}

Era uma vez, e como faz tempo aquela vez, os animais da floresta saíram em busca de comida.

Os pássaros voavam alto, acima das árvores, procurando.

Os esquilos cavavam em todos os seus esconderijos, procurando.

Os macacos balançavam de árvore em árvore, procurando. Nada acharam.

Não muito longe, havia um campo com muito milho. Quando os animais ouviram falar do campo, saíram correndo para encontrá-lo. Os pássaros saíram voando também.

Dona Tartaruga estava chape, chape, chapinhando no rio. Ela viu os pássaros voando. Eles batiam suas asas, fru-fru! fru-fru! fru-fru!

Estava um silêncio na floresta e Dona Tartaruga se sentia só. Então ela decidiu seguir os pássaros e os animais. 
Dona Tartaruga foi andando até chegar a um vasto campo. Lá, viu seus amigos se empanturrando com milho maduro.

Os pássaros gritavam para Dona Tartaruga:

- Vá embora, Dona Tartaruga! Vá embora, ou Seu Vigia vai pegá-la.

Dona Tartaruga disse:

- Não se preocupem comigo. Vou tomar muito cuidado com Seu Vigia.

Mas, uma vez no campo, o milho era alto demais para Dona Tartaruga ficar atenta.

De repente, lá estava Seu Vigia. Ele estava de pé com uma vara na mão.

Os pássaros bateram as asas e saíram voando, fru-fru! fru-fru! frufru! Deixaram Dona Tartaruga sozinha.

- Ahá! - disse Seu Vigia. - Aqui está um ladrão que não vai fugir.

Agarrou Dona Tartaruga e enfiou-a no seu saco de viagem.

Enquanto caminhava pelo campo, Seu Vigia cantava uma canção. Era um calipso com uma melodia tão animada, que os pés de Dona Tartaruga sentiam uma comichão para dançar.

Ora, Dona Tartaruga adorava dançar mais do que qualquer coisa. Então, quando ouviu Seu Vigia cantar, ela gritou:

- Ei, Seu Vigia, isso é que é um calipso de verdade, amigo!

- Gosta da minha canção? Eu mesmo faço a letra, sabia? - disse Seu Vigia.

- Sério?! - disse Dona Tartaruga. - Eu também faço canções.

- Bem, por que você não faz uma canção para mim agora? - perguntou Seu Vigia.

Dona Tartaruga disse então:

- Sabe, quando canto, gosto de dançar e preciso de bastante espaço.

Assim, Seu Vigia tirou Dona Tartaruga do saco e colocou-a no chão.

Dona Tartaruga começou a cantar uma canção. Enquanto cantava, ela movimentava os pés.

Ela dançava para a direita e dava uma volta.

Ela dançava para a esquerda e dava uma volta.

Ela saltitava e dançava. 
Ela girava e saracoteava.

Ela ia dançando em direção ao rio.

Era uma melodia fácil de cantar. Era uma melodia animada para dançar. Logo, Seu Vigia também estava dançando. Ele dançava acompanhando o ritmo. Sacudia os ombros e estalava os dedos.

E ele dançava para a direita e dava uma volta.

Ele dançava para a esquerda e dava uma volta.

Ele saltitava e dançava.

Ele girava e saracoteava.

E ele dançava em direção ao rio.

Dona Tartaruga dançava cada vez mais depressa e dava passadas cada vez maiores.

Seu Vigia tentava acompanhar o ritmo de Dona Tartaruga.

Dona Tartaruga rodopiava na ponta dos pés, saltitava e girava.

Seu Vigia acompanhava cada rodopio, cada salto e cada giro.

Ele não percebeu para onde Dona Tartaruga estava indo, até que ouviu um enorme TCHIBUM!

Dona Tartaruga tinha mergulhado no rio e já nadava para longe.

Dança da Tartaruga

Cante e dance, tralalalá,

Pule e dance, tralalalá.

Escute a música tocando

E o tambor de aço rufando,

Cante e dance, tralalalá.

Quando a música é boa, você tem de dançar! A tartaruga está em perigo, mas mesmo assim ela dança... 


\section{Referências}

GREEN, Mona. How the Animals Got Their Tails. Cambridge University Press, 1996.

HALLWORTH, Grace. Dancing to the River. Cambridge University Press, 1996. 